\title{
Aids, tempo e suas renitências: socialidades, emoções e políticas em uma rede social online
}

\author{
LUCAS PEREIRA DE MELO \\ Universidade de São Paulo, Ribeirão Preto, São Paulo, Brasil \\ lpmelo@usp.br
}

DOI 10.11606/issn.2316-9133.v29i2pe179821

\begin{abstract}
resumo Este artigo problematiza as relações entre doença, tempo, socialidade, emoção e prática estatal no campo do HIV/aids a partir da interlocução com pessoas que vivem com HIV/aids num grupo fechado no Facebook. Faz-se isso ao analisar a socialidade no grupo, com destaque à confiança na cronificação da infecção pelo HIV e às postagens que denunciavam a intensificação do desmonte da política brasileira de aids decorrentes de ações governamentais. Tais postagens geraram 'tretas' entre membros do grupo. Seguir as 'tretas' para compreender suas gramáticas política e emocional permitiu interpretar os significados atribuídos pelos interlocutores às políticas públicas de saúde, o que possibilitou analisar o lugar do Estado nessas políticas.
\end{abstract}

palavras-chave HIV/aids. Sofrimento social. Temporalidades. Etnografia virtual. Políticas de saúde.

AIDS, time, and its stubbornness: sociality, emotions, and policies in an online social network

abstract The article problematizes the relationship between illness, time, sociality, emotion, and state practices. It is based on ethnographic research with people living with HIV/AIDS engaged in a group on Facebook. It analyses sociality in the group focusing on the trust on HIV infection as chronic illness and the posts about the governmental actions that dismantle the Brazilian AIDS policy. Those posts generate 'tretas' (a kind of conflict) between the group's members. The interpretation of the meanings attributed by the informants to the public health policies and the comprehension of the political and emotional grammars of the 'tretas' allows analyses the state place into these policies.

Keyword HIV/AIDS. Social suffering. Temporalities. Virtual ethnography. Health policies. 
El sida, el tiempo y sus renitencias: socialidades, emociones y política en una red social online

resumen Este artículo problematiza las relaciones entre la enfermedad, el tiempo, la socialidad, la emoción y la práctica estatal en el campo del VIH/SIDA al hablar con personas que viven con el VIH/Sida en un grupo cerrado en Facebook. Lo hace analizando la socialidad del grupo, con énfasis en la confianza en la cronificación de la infección por VIH y los cargos que denunciaron la intensificación del desmantelamiento de la política brasileña de lucha contra el Sida como resultado de las acciones gubernamentales. Tales mensajes generaron "tretas" entre los miembros del grupo. El seguimiento de las "tretas" para comprender sus gramáticas políticas y emocionales permitió interpretar los significados atribuidos por los interlocutores a las políticas de salud pública, lo que permitió analizar el lugar del Estado en estas políticas.

palabras clave VIH/Sida. Sufrimiento social. Etnografía virtual. Temporalidades. Políticas de salud.

\section{Eu seguia as 'tretas'}

Neste artigo apresento dados empíricos e reflexões teóricas produzidos numa etnografia que buscou compreender as relações entre cronicidade da infecção pelo vírus da imunodeficiência humana (HIV), segredo sobre a sorologia e experiências de sofrimento social, conduzida entre 2017 e 2020 num grupo fechado no Facebook criado em 2009 por uma Rede que reúne pessoas que vivem e convivem com HIV/aids. O grupo tem como propósito oferecer acolhimento, informação e ajuda mútua. Além do grupo fechado no Facebook, a Rede conta com site público, perfil em redes e mídias sociais na internet (Twitter, Facebook, Instagram, YouTube), mais de 4 mil membros, quatro grupos no WhatsApp, um canal no Telegram e um blog.

O trabalho de campo consistiu na observação e acompanhamento das interações no grupo no Facebook, na interlocução com os interlocutores nessa rede social, na análise do conteúdo produzido e compartilhado por integrantes do grupo e na realização de entrevistas semiestruturadas online ou presencialmente. O projeto foi aprovado pelo Comitê de Ética em Pesquisa, conforme a Resolução no 510/2016 do Conselho Nacional de Saúde.

Desde meu ingresso no grupo (em fevereiro de 2017) até as eleições presidenciais de 2018 que elegeu Jair Bolsonaro para Presidente da República, as postagens que engajavam as pessoas versavam sobre compartilhamentos de dúvidas e experiências relativas à vivência com HIV/aids. No entanto, a partir da eleição, o grupo foi inundado por postagens sobre 
politica $^{1}$, categoria êmica que incluía pronunciamentos de Bolsonaro sobre HIV/aids e, a contar de janeiro de 2019, as ações de seu governo cujos resultados era o aprofundamento do desmonte da resposta brasileira à epidemia. Em geral, as postagens sobre 'política' geravam interações bastante acaloradas, cujos conflitos eram denominados de 'tretas'. Seguir essas 'tretas' se mostrou rentável, em termos etnográficos, uma vez que produziram não só uma crise relacional no grupo, como desestabilizou as narrativas que o construíam como uma 'família' e um espaço de ajuda mútua.

Lia as postagens sobre 'política' e me lançava entre os links em busca de sentidos e de entendimentos ao que fora capaz de gerar tanta movimentação no grupo. As 'tretas' nos remetiam ao Brasil que vira um governo com vocação autoritária assumir o poder. Suas primeiras ações em setores como saúde e previdência social caíram como pedras no teto das políticas e dos direitos conquistados ao longo da história brasileira de aids. No decurso do trabalho de campo, o compartilhamento dessas postagens colocava em evidência as relações entre doença, tempo, socialidade, emoção e prática estatal. Interessa-me aqui os modos como tais relações, histórica e socialmente construídas, penetravam em cotidianos tecidos em torno de experiências localizadas e corporificadas (HARAWAY 1995), como aquelas vividas e narradas pelas pessoas com quem mantive interlocução na pesquisa.

No grupo, as partilhas sobre 'politica' emaranhavam as ações estatais a um conjunto de relatos inscritos na lógica dos sofrimentos psíquicos decorrentes do conhecimento sobre tais ações, de maneira que um dos interlocutores chegou a indagar numa postagem de 02 de maio de 2019 se havia uma 'depressão coletiva no grupo'. Sob a alcunha da depressão se inscreviam entidades psiquiátricas comumente narradas ali e que, no primeiro semestre daquele ano, se tornaram mais frequentes: depressão, ansiedade generalizada, isolamento social, transtorno afetivo-bipolar, transtorno do estresse pós-traumático, ideação suicida, síndrome do pânico. A despeito das definições psicopatológicas destes sofrimentos oferecidas pela Psicologia, Psicanálise e Psiquiatria organicistas que tendem a delimitá-los no âmbito individual e intrapsíquico, o foco aqui é abordá-las como idiomas para expressar sofrimento social. Ou seja, busco destacar o quanto as propostas de intervenção estatal envolvidas na administração e enfrentamento da epidemia de HIV/aids podem, intencionalmente ou não, intensificar o sofrimento humano (KLEINMAN; DAS; LOCK 1997). Faço isso ao problematizar o lugar do Estado e das políticas públicas dirigidas ao enfrentamento da epidemia de HIV/aids no Brasil, de maneira a deixar em relevo as concepções e significados que as pessoas que vivem com HIV/aids, membras do grupo no Facebook, atribuíam a tais políticas, bem como as ações, emoções e socialidades que emergiram nos comentários às postagens sobre este tema.

O objetivo aqui é pensar, a partir do diálogo com autores como Kleinman, Das e Lock (1997), como esses elementos configuram subjetividades e trajetórias de vida marcadas

\footnotetext{
${ }^{1}$ Utilizo aspas simples e itálico nos fragmentos de fala de interlocutores quando inseridos dentro do texto. A mesma marcação é atribuída às categorias e expressões êmicas.
} 
por experiências de sofrimento social resultantes daquilo que o poder político, econômico e institucional faz às pessoas, influenciando, inclusive, a maneira como elas reagem aos problemas humanos. Para esses autores, o sofrimento social inclui "condições que simultaneamente envolvem questões de saúde, bem-estar, legais, morais e religiosas" que "desestabilizam categorias estabelecidas" (p. ix) como trauma, dor, transtornos, violências, aids. O conceito de sofrimento social, concebido como resultante das íntimas relações entre indivíduo e sociedade, desafia as concepções psicopatológicas que se notabilizam por visões essencializadas, medicalizadas e individualistas. Por isso, o sofrimento social precisa ser pensado a partir de sua base intersubjetiva, de maneira a situá-lo como uma experiência social que "arruína o coletivo e as conexões intersubjetivas da experiência e danifica gravemente a subjetividade" (p. $\mathrm{x}$ ).

Este artigo está estruturado em três seções, além desta primeira. $\mathrm{Na}$ segunda, Confianças, garantias e certezas, são apresentados aspectos da socialidade no grupo, com ênfase na confiança no tratamento antirretroviral. Na terceira, As 'tretas' e suas gramáticas, parto das postagens sobre 'politica' e das 'tretas' para discutir as fissuras da confiança discutida na seção anterior e suas inflexões na socialidade e na produção e/ou intensificação de experiências de sofrimento social entre os membros do grupo. Na quarta e última seção, Renitências, teço algumas considerações sobre as relações entre tempo, emoções e política na construção da “aids de agora”, priorizando um olhar ao papel do Estado nestes processos.

\section{Confianças, garantias e certezas}

Em 2017, quando iniciei a pesquisa de campo no grupo, já se ouvia falar de interrupções ou fracionamentos de medicamentos antirretrovirais que eram distribuídos nos serviços do Sistema Único de Saúde (SUS). A despeito do que corria em outros sítios, no grupo, me deparei com um clima de otimismo que se podia observar na confiança no tratamento e na certeza de que a aids era uma crise atada alhures. Para Giddens (1991), na modernidade tardia, a confiança é derivada de uma forma de "fé" na credibilidade de uma pessoa ou de um sistema perito. Os sistemas peritos se referem "a sistemas de excelência técnica ou competência profissional que organizam grandes áreas dos ambientes material e social em que vivemos" (GIDDENS 1991: p.37), como direito, medicina, arquitetura, etc. Assim, a "fé" não é tanto nos seus profissionais, mas na autenticidade do conhecimento perito que eles produzem e aplicam. Dessa forma, tais sistemas fornecem "garantias" que, por meio da aplicação de tais conhecimentos técnicos, participam da monitoração do comportamento e seus contextos, de maneira que são sempre passíveis de serem revisados.

No grupo etnografado, a confiança no sistema perito biomédico se evidenciava na busca e compartilhamento de informações científicas sobre aids que reforçavam, cotidianamente, a "fé" no tratamento antirretroviral e no progresso linear da ciência em direção à cura. Em geral, as postagens que tratavam diretamente da experiência de viver com $\mathrm{HIV} /$ aids tematizavam a centralidade da terapia antirretroviral e da gestão do segredo sobre a sorologia, o que podia incluir: adesão ao regime terapêutico (medicação, atividade física e 
alimentação considerada saudável); tipos de medicações e seus efeitos colaterais; permuta de esquemas de terapia antirretroviral; monitoramento das 'taxas' (carga viral e CD4, principalmente); controle do estresse; preocupações com o surgimento de novos sintomas ou de uma infecção oportunista; problemas na dispensação das medicações no SUS; segredo e revelação da sorologia; relações familiares; medo da rejeição e abandono socioafetivo; relações afetivo-sexuais após o diagnóstico; situações de preconceito e discriminação; e o enfrentamento do estigma diante da condição. Por meio dessas partilhas, a socialidade entre membros do grupo permitia a produção de ajuda mútua, o que tinha um papel fundamental no enfrentamento das experiências de sofrimentos decorrentes do viver com HIV/aids.

Nomeadamente em 2017, postagens que pautassem temas mais 'politicos' não eram bem recebidas, o que assinalava que ali não se tratava de um grupo de ativismo em aids, embora houvesse alguns ativistas entre os membros. $\mathrm{O}$ aparente desinteresse das pessoas se fazia perceber, por exemplo, na matemática das reações às postagens. Algumas delas angariavam algo em torno de uma dúzia de curtidas. Em minhas análises, via ali uma atmosfera que guardava algumas relações com o processo contínuo e intenso de positivação das pessoas que vivem com HIV/aids, conforme evidenciado por Claudia Cunha (2012) em sua etnografia com jovens vivendo que atendiam a oficinas pedagógicas, cujo objetivo era a formação de protagonistas e multiplicadores na prevenção da aids.

Por positivação desses sujeitos, a antropóloga entende o processo de construção do "(soro)positivo feliz", no qual "a saúde aparece como uma espécie de dever, uma ética e estética que inviabiliza o aparecimento da feiura, da dor, do adoecimento e da morte" que caracterizaram a "aids de antes" (CUNHA 2012: p.73). Nas oficinas etnografadas pela autora, o foco principal era o manejo da sexualidade, o que requeria uma pedagogização de si capaz de modelar um sujeito moral que se responsabiliza pelo próprio cuidado (como adesão ao tratamento) e do outro, prevenindo-se e evitando a disseminação do vírus. Entre os interlocutores era possível perceber com mais força a pedagogização operada pelos profissionais da saúde com foco no autocuidado, mas também entre membros do grupo por meio do compartilhamento de seus saberes e experiências. $\mathrm{O}$ foco no autocuidado permitia a construção cotidiana de um pilar fundacional caracterizado pela relação linear (ao menos no nível discursivo) entre tratamento-tempo-normalidade. Este pilar, de inspiração biomédica e individualista, consistia no estímulo à adesão ao tratamento, o que incluía não só a ingestão diária de medicamentos, como a realização de exames e mudanças de estilo de vida que, com o tempo, levaria à condição de carga viral indetectável, ao aprendizado sobre os cuidados cotidianos e, consequentemente, à 'vida normal'.

No acompanhamento das interações no grupo e nas interlocuções que mantive individualmente com seus membros, assim como na etnografia de Cunha (2012), a positivação da experiência de viver com HIV/aids era dependente da separação entre a "aids de antes" e a "aids de agora". Tal separação repousava suas discursividades em narrativas heroicas que se pretendiam consolidadas e que destacavam os desenvolvimentos 
biotecnológico, político, econômico e sanitário e a maneira como eles se capitalizavam em conquistas na tessitura das respostas políticas à epidemia (BASTOS 2002).

Assim como Cunha (2012), assumi a "aids de antes" e a "aids de agora" como categorias analíticas fundamentais nesta etnografia, uma vez que destacam as temporalidades da epidemia, pois nas narrativas dos meus interlocutores ela abrangia as maneiras próprias e criativas como, em suas experiências, se integravam a longa duração da infecção pelo HIV, a possibilidade de viver com a sorologia em segredo e suas inflexões no aumento da sobrevida e na constituição de um corpo que sentia o tempo não pela sua pobreza, mas pela sua produtividade. A "aids de agora" se erigiu no campo sociopolítico e biomédico brasileiro por meio de processos difusos, capilares e múltiplos que deixou em relevo a cronificação da infecção pelo HIV em contexto local e nublou as relações entre Estado, mercado e biotecnologia, bem como a manutenção através dos anos da macro-configuração da epidemia em escala global, como assinala Bastos (2002).

Se, a princípio, cheguei a seguir algumas pistas que pareciam me levar a entender o clima de otimismo no grupo como derivado das vinculações do seu criador com o então Departamento de IST, Aids e Hepatites Virais do Ministério da Saúde, o aprofundamento das relações em campo e o diálogo perene com a literatura me fez vinculá-lo à gênese social, econômica e tecnocientífica dessa "aids de agora", derivada do aprisionamento da aids como crise ("aids de antes") num passado interditado pela biomedicina e suas tecnologias (BIEHL 2011; SEFFNER; PARKER 2016; SANGARAMOORTHY 2018).

Nas interações no grupo, a "aids de antes" era uma aids atada, pretérita e superada, pois nela se fixaram as imagens de morte. Ataram-se não só as imagens e as representações da aids, narradas no grupo investigado como obsoletas e sucumbidas à ciência, mas a solidariedade como estratégia que permitiu construir a doença como um problema político, comunitário e a maneira como, em alguma medida, ela se fez sentir nas ações estatais e no movimento social. Na análise de Seffner e Parker (2016), a experiência recente da resposta brasileira à aids tem se caracterizado pela estratégia medicalizante que promove o "desperdício da experiência” acumulada:

[g]rande número de ações em aids perdeu esta noção de projeto político, e associamos isso a um dos efeitos do tratamento, que individualiza as abordagens, não necessita e nem deseja lidar com sujeitos coletivos ou movimentos sociais. A medicalização convive muito bem com a individualização. (...) A medicalização traz consigo uma ontologia individual liberal, enquanto, em seu início, a resposta brasileira à aids, com sua forte conexão com os direitos humanos e a ênfase na solidariedade, apontava para uma ontologia social (...)" (SEFFNER; PARKER 2016: p.301). 
Foi esta "ontologia individual liberal" produzida nas teias entre Estado, mercado e biotecnologia que aparecia nas postagens do grupo não só por meio das temáticas que punham em circulação, mas também pela confiança que alguns interlocutores expressavam ao se referirem à política e às legislações de aids como intocáveis e refratárias às ações de governos e aos reflexos das conjunturas econômicas. Tal confiança veio à tona com as postagens que afirmavam ou sugeriam estar em curso um processo gradativo de desmonte da política brasileira de aids. Essas discussões eram disparadas pelo compartilhamento de notícias e de postagens de outras páginas e perfis em redes sociais online. Em 05 de janeiro de 2019, Júlia² escreveu:

[postagem] Queria só trazer notícias boas, abrir tópicos legais, mas... não tá dando! Brasil vai voltar à época do surto de gonorreia, HPV na “modalidade" verrugas e Aids no nível de mortalidade dos anos 80, sobrecarregando os hospitais e causando caos na saúde porque ISTs (infecções sexualmente transmissíveis) NÃO SÃO DO ÂMBITO, DE RESPONSABILIDADE DA SAÚDE PÚBLICA, SEGUNDO O NOVO MINISTRO DA SAÚDE! Taokei pra vocês?! [a postagem vinha seguida do print de postagem de outra pessoa $]^{3}$.

"Não haverá politica pública de prevenção para a AIDS, pois se trata de uma questão moral. Conversas sobre sexualidade, como aquelas envolvendo métodos de proteção contra doenças sexualmente transmissíveis, devem ser abordadas pelas famílias, e não pelo governo."

Luiz Henrique Mandetta Ministro da Saúde

[comentário à postagem] Misericórdia! Só tem 3 meses que descobri [que vive com HIV/aids]. Ainda nem estou indetectável, meu Deus! Como vamos fazer para sobreviver caso eles tirem nossos medicamentos... Vamos ter que fazer algo: ir para as ruas exigir nossos direitos de cidadãos

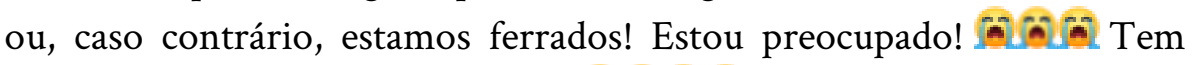

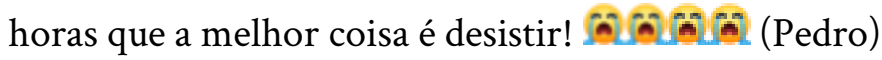

\footnotetext{
${ }^{2}$ Por questões éticas, utilizo nomes fictícios.

${ }^{3}$ Mantive as grafias e a formatação original das postagens. Para garantir a compreensão do fluxo dos diálogos, deixo em evidência se o texto se tratava de postagem, comentário à postagem ou resposta ao comentário.
} 
[resposta ao comentário] Essas falas sensacionalistas são só pra causar. A distribuição de medicamentos para IST é lei! Eles podem até não gostar, mas é lei e não podem mudar, precisam mexer muitos pauzinhos pra isso. Mas não vai acontecer até porque, entre o custo de prevenir e o custo de remediar, eles vão preferir prevenir. Caso contrário será um colapso nos hospitais e aí o Brasil quebra de vez. É uma questão matemática humanitária. Triste, mas é a verdade. (Túlio)

As ações de agentes estatais divulgadas no grupo pareciam ligar alguns pontos que haviam sido soltos na construção da narrativa da "aids de agora" e seu traço individualizante que circunscrevia a condição de viver com HIV/aids aos serviços de saúde e à intimidade de cada um, como segredo. Nesses atos de religação, a primeira operação era destacar o pano de fundo que garantia o acesso ao tratamento antirretroviral: o SUS. As matérias compartilhadas versavam sobre ações governamentais que recaíam sobre o sistema público de saúde, afetando políticas específicas, o que colocava a necessidade de as pessoas que vivem com HIV/aids se engajarem na defesa do SUS - uma pauta unificadora de diversas lutas, segundo colocavam alguns interlocutores.

[postagem] Para os que votaram no idiota inútil que está na presidência da república: Ministro da Saúde defende fim da gratuidade universal do SUS [seguida do compartilhamento do link] https://operamundi.uol.com.br/politica-e-economia/58711/ministroda-saude-defende-fim-da-gratuidade-universal-dosus?fbclid=IwAR3Wk9weSIPXOCUhyPyxKuxcUO54H0dfs7cjODiFhfcZKpPW3pQbD61fp0 (Flaviano, 28/05/2019)

[comentário à postagem] Gente, não já foi dito que não afetará os nossos medicamentos? (Ademir)

[resposta ao comentário] O voto foi uma arma e vai nos atingir cedo ou tarde. O ministro da saúde é alinhado com companhias de seguro de saúde e eu não sei de onde tiram que sem seguridade social haverá SUS. Sem SUS, sem tratamento nem prevenção. O departamento de AIDS e ISTs já não existe mais mesmo. (Rafael)

[resposta ao comentário] Ademir, não afetará, mas isso é um grande recado. Países liberais não custeiam tratamento de HIV. Nos EUA, até anos atrás, para um imigrante ter direito ao Green Card tinha que fazer 
exames e, dentre eles, o de HIV, para o governo saber se iria custear ou não o tratamento. (Bruno)

Nessas conversas, o acesso universal e a gratuidade do tratamento antirretroviral emergiam mais como uma "bala mágica" (BIEHL 2011) fabricada pelas indústrias farmacêuticas e pela boa vontade política de alguns governantes, e menos como resultado das lutas e das fricções entre movimento social, sociedade civil, campo biomédico e Estado. Conforme comentário de Ademir, havia uma preocupação com o tratamento em termos de sua gratuidade e acesso, mas que o colocava não como parte do alinhavo entre políticas públicas tessidas no contexto do SUS, e, sim, numa chave individualista, própria da "ontologia individual liberal" (SEFFNER; PARKER 2016), pois centrava a preocupação em saber se seus direitos seriam ou não afetados. Em todo caso, como alertado por Bruno, se as postagens de 'política' não indicavam uma ameaça imediata, introduziam no horizonte um perigo, um sinal de alerta.

Nesses momentos, eram comuns os pedidos de informações sobre o tratamento da aids em outros países e as comparações entre sistemas de saúde universais e seletivos. Aqui o papel de interlocutores que viviam fora do Brasil era fundamental, pois elencavam as condições para migração, acesso à saúde, custos decorrentes e estratégias necessárias para manter a adesão ao tratamento. Entre os comentários ia se delineando a existência de profundas e simbióticas relações, no contexto brasileiro, entre práticas estatais, mercado e acesso à saúde.

[postagem] Olá pessoal, sei que muitos aqui perguntam sobre morar fora [do Brasil] e as medicações. Faz 4 meses que estou na Argentina e só agora precisei pegar remédios aqui (vim com 5 meses de remédio trazido do Brasil na mala). Seguinte, é muito simples e sem muita enrolação para retirar apenas a medição pelo sistema de saúde da ARGENTINA, vc vai precisar de: 1 - sorriso na cara; 2- está com o laudo médico ou a prescrição dos remédios feita no Brasil; 3- se possível estar com um dos potinhos do seu remédio; 4- o lugar na minha cidade se chama CEDITet, creio que tem o mesmo nome em todas as cidades; 5- ter algum documento de identificação. (...) É possível receber pelos Correios mandados do Brasil, porém a aduana é um porre, maior frescura e ainda corre o risco de ter que pagar pela importação. No mais, quem tiver alguma dúvida, pergunta nos comentários ou chama no inbox [mensagem privada pelo Facebook]. Ficarei feliz em ajudar. (Miguel, 23/01/2019)

[comentário à postagem] Eu também fiz a mesma coisa quando vim pra Austrália, só que aqui não consigo a medicação gratuita pelo governo, peço pra mandarem do Brasil a cada 6 meses e chega em 15 dias! Mando 
mensagem pra minha infectologista e ela faz a receita pra 6 meses! Mas têm países que fornecem, não tive essa sorte. (Henrique)

[resposta ao comentário] Henrique, ouvi dizer que aí eles pedem o exame pra conceder ou não o visto. (Everton)

[resposta ao comentário] Sim meninos, pra renovar meu visto tive que passar pela médica pra saberem como estava minha saúde e ela emitir um laudo que eu recebo o remédio do Brasil e eles não iriam custear minha medicação. (Henrique)

[resposta ao comentário] quanto custa a medicação aí na Austrália, Henrique? (Tércio)

[resposta ao comentário com foto]

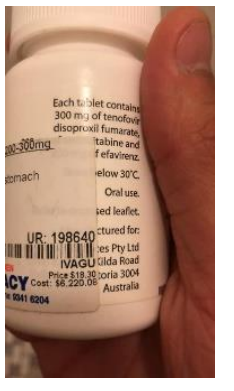

Tércio, nem sei quanto é aí no Brasil, mas fiquei sabendo que também é super caro o tratamento mensal (Henrique)

Como veremos adiante, a migração como projeto em caso de agravamento da situação estava intimamente relacionada com alguns pertencimentos sociais dos interlocutores (como classe social e raça), o que não era uma opção a todos ali. Assim, se nos primeiros dois anos de trabalho de campo, a socialidade no grupo tinha sido marcada pela busca de acolhimento, pelo compartilhamento e elucidação de dúvidas comezinhas sobre viver com $\mathrm{HIV} /$ aids, e pela troca de experiências que o caracterizava como um espaço de ajuda mútua e de biossocialidade (RABINOW 1996), no ano de 2019, especialmente em seu primeiro semestre, acompanhei a mudança de tom nos debates levados a cabo no grupo.

As postagens sobre 'politica' pareciam querer arrancar, à força, as pessoas de seus casulos íntimos e de seus segredos, na medida em que denunciavam a desaposentadoria de pessoas vivendo com HIV/aids, os problemas de distribuição de medicamentos antirretrovirais e as mudanças ocorridas tanto na estrutura do Ministério da Saúde, como em sua atuação. Ao fazer isso, se colocava aos interlocutores a necessidade de pensar a aids na chave da solidariedade e enfatizava a existência de temporalidades que se vinculavam mais por suas continuidades que por suas rupturas, escancarando, assim, o papel do Estado na garantia do tratamento e a aids como um problema político. Parecia ganhar nitidez ali que 
as ataduras que mantinham a aids como um problema do passado estavam a se esgaçar, a se puir com o tempo.

\section{As 'tretas' e suas gramáticas}

Em 2019 já havia, no movimento social, no meio acadêmico e sanitário, certo consenso em torno da crise da resposta brasileira à epidemia de aids derivada das crises econômica e política que o país experimenta (AGOSTINI et al 2019). No grupo investigado havia, igualmente, disputas tanto nas narrativas que anunciavam tal crise quanto na sua crença ou rechaço. Como analisado na seção anterior, as postagens sobre 'politica' introduziam (ou buscavam introduzir) algumas contradições na linearidade rumo ao progresso presente nos discursos de profissionais e gestores da saúde, e mesmo de algumas pessoas que vivem com HIV/aids. Afinal, em quem acreditar? Nas interações online entre membros do grupo, essas disputas ganhavam os contornos de um contexto social mais amplo inundado pelo compartilhamento de informações falsas - as chamadas fake news ${ }^{4}$.

A aura de neutralidade e o peso da objetividade dos discursos peritos e oficiais produzidos e reproduzidos nos encontros clínicos embasados em evidências científicas pareciam estar diante de uma grande afronta. Dilema impróprio, e talvez inimaginável, na modernidade tardia com seus amplos e intensos processos de racionalização cristalizado, no caso em tela, na confiança na biomedicina moderna. Outrossim, há que se destacar a intensificação, desde os anos 2000, da individualização neoliberal e da garantia de direitos via legislações diversas - a lei como solução. Este foi, a partir de janeiro de 2019, o pano de fundo contra o qual se desenvolveram as 'tretas' entre participantes do grupo. Elas se voltavam contra a harmonia da ajuda mútua buscada pelo/no grupo.

A princípio, as 'tretas' pareciam apenas tensões entre pessoas favoráveis e contrárias ao novo Presidente que, por vezes, era mediada por outros membros que reconheciam o perigo e a necessidade de 'estar atentos', mas que não viam, ainda, motivos para desesperos. $\mathrm{Na}$ medida em que acompanhava as interações no grupo e entrevistava, individualmente, algumas pessoas, fui delineando, como assinalado na seção anterior, a existência de uma confiança na política de aids e nas legislações a respeito, na qual o acesso à terapia antirretroviral gratuita era um símbolo.

Além da terapia medicamentosa em si, a Lei Federal no 9.313, de 13 de novembro de 1996, que instituiu a distribuição universal e gratuita dos medicamentos, era acionada como a garantia jurídica do direito à saúde, o que, na visão de alguns interlocutores, era irrevogável. Esta confiança e garantia eram tão sólidas para alguns interlocutores que as postagens sobre 'política' pareciam querer desmanchá-las no ar, parafraseando a clássica frase de Marx e Engels (2005). Entre as pessoas descrentes, pairava uma sensação de traição e de

\footnotetext{
${ }^{4}$ Assim como em outros países, no Brasil, as fake news têm sido utilizadas para manipulação das massas e participam diretamente da construção das crises em tela (VITORINO; RENAULT 2020).
} 
terem sido enganadas por profissionais da saúde, pelos legisladores e pelos gestores da política de saúde, dada a confiança que lhes fora depositada.

Uma das 'tretas' na qual tais aspectos ganhou um relevo importante ocorreu entre Júlia e Humberto em maio de 2019, culminando, inclusive, com a saída dele do grupo. A 'treta' se deu na esteira de comentários à postagem feita por Gilson a respeito da decisão do Supremo Tribunal Federal (STF) sobre o custeio, por parte do SUS, de medicamentos de alto custo. Nestes comentários, deu-se um debate sobre se a decisão teria, ou não, efeito sobre os medicamentos antirretrovirais. Embora já nos primeiros comentários tenha se estabelecido um consenso de que não afetava a política de aids, sucedeu-se uma discussão em torno da Lei Federal no 9.313/1996, na qual uns defendiam que ela, como qualquer outra lei, poderia ser mudada, e outros que sustentavam a impossibilidade de mudança.

[comentário] Gente, vocês têm que ver a fonte da notícia! TEM VÁRIOS SITES QUE SÓ FALAM MENTIRAS! IMPOSSÍVEL ACABAR OS REMÉDIOS! ISSO É IR CONTRA A VIDA HUMANA! SE INFORMEM ATRAVÉS DE FONTES SEGURAS ANTES DE POSTAR AS COISAS AQUI NO GRUPO! (Humberto)

[comentário] Humberto, "IMPOSSÍVEL ACABAR OS REMÉDIOS!" não é, não! Pode ser desumano, pode significar que você, eu e a maioria esmagadora no Brasil de pessoas vhivendo desenvolvam quadro de Aids e venham a morrer, acarretando até um colapso no atendimento dos hospitais, que não vão dar conta... Mas, IMPOSSÍVEL REVOGAR A LEI?! NUM É NÃO! E, se eu estiver errada, algum advogado presente no grupo pode me fazer a gentileza de corrigir, eu até suplico! (Júlia)

[resposta ao comentário] Júlia, não vai acontecer! Calma! (Humberto)

[resposta ao comentário] Humberto, no momento, eu estou calmíssima! Mesmo porque eu sou mulher, hétero, tenho opções até de sair do país, não desenvolvi quadro de Aids e meus níveis de cd4 e cd8 são excelentes (os dois acima de 1.200 com relação de 1,02\%), estou indetectável (o que, ficando sem remédio, levaria o mesmo tempo para o vírus voltar a se replicar de quando me infectei). Enfim, eu não estou num grau de vulnerabilidade tão alto como MUITA GENTE no Brasil que é soropositiva. MAS EU NÃO QUERO PERDER O DIREITO AO TARV [terapia antirretroviral] E QUE NINGUÉM PERCA! Se a pessoa não quer se tratar, a questão é dela! No entanto, há milhares que querem e muitos que dependem radicalmente que não haja nenhuma perda de direitos porque não vão ter pra onde ir, não vão poder bancar o TARV, vão 
adoecer rápido etc. O que não se pode é achar que ficar calmo é sinônimo de ficar inerte, no mundo da lua, se enganando com a realidade do que pode CONCRETAMENTE acontecer e já está dando indícios disso. (Júlia)

[resposta ao comentário] Júlia, meu Deus! Mas nunca vai acontecer isso! Vcs estão colocando coisas na cabeça que não existe! Ninguém pode ir contra os direitos do próximo!!!! Chega! Acabei aqui a conversar! Se eu ficar dando ouvido a alguns de vcs não vou nem dormir de noite! (Humberto)

[comentário] E Humberto, tu estás esquecendo de uma coisa mega importante: mesmo que ele não consiga revogar a Lei que embasa a garantia do nosso tratamento (que inclui a distribuição gratuita dos medicamentos pelo SUS), ele pode ir fazendo uma mudança aqui e acolá de GESTÃO e, embasado nisso, CORTAR, RACIONAR a medicação. Isto, inclusive, já está ocorrendo! (Júlia)

[resposta ao comentário] Olha eu não acredito em nada disso que vcs estão dizendo tá! Acho absurdo! Vc está preocupada demais por uma coisa que nunca vai acontecer! Relaxa, viva sua vida em paz, remédio nunca vai faltar! Assunto encerrado, obrigado! (Humberto)

O assunto não se encerrou neste ponto, como queria Humberto. Pelo contrário, se alongou um pouco mais em torno da repetição desses argumentos até o limite das afrontas pessoais. O caso de Humberto me chamou atenção por sua confiança na lei, pois, diferente de algumas pessoas assumidamente eleitoras e apoiadoras do atual Presidente, em momento algum nesta 'treta', nem nas outras em que esteve envolvido, ele se colocou como 'bolsominion', embora tenha sido acusado. A curiosidade em tentar conhecê-lo um pouco mais me levou, primeiro, a adicioná-lo como amigo em meu perfil pessoal no Facebook; segundo, a entrevistá-lo.

Humberto é um homem negro, gay, com 25 anos, estudante universitário, classe popular, solteiro, paulista e vive com sua família numa cidade do interior do Rio de Janeiro. Ele relatou ter saído do grupo porque ingressou nele buscando manter contato com 'pessoas na minha mesma situação. Então eu ia ficar informado sobre as coisas, como notícias sobre o HIV. Mas, assim, eu gosto de noticias verdadeiras. Não gosto de notícias infundadas. Ainda mais desses sites $^{5}$ que dão noticias falsas. Tem muita gente que não vai verificar se a notícia é verdadeira. Eu saí por isso'. Ao longo da entrevista, Humberto salientou que saber e acreditar na possibilidade

\footnotetext{
${ }^{5}$ Refere-se a sites que não pertenciam à grande mídia e, segundo os interlocutores, se alinhavam a grupos políticos de esquerda. Na 'treta' em análise, tratava-se do site Catraca Livre (https://catracalivre.com.br/).
} 
de viver com HIV/aids como doença crônica foi importante para ele aceitar o diagnóstico. Em suas palavras:

Infelizmente eu peguei essa doença crônica e infelizmente terei que viver com isso a vida toda, até chegar a cura definitiva. Mas quando eu descobri que, na verdade, tratamento tem, só não tem aquela cura definitiva, eu me dei paz e continuei minha vida com a cabeça erguida, fazendo as coisas, tomando cuidado, juízo. Com o tratamento a pessoa soropositiva tem a possibilidade de continuar vivendo igual a qualquer outra pessoa. Então, acabei aceitando, mas, como eu te falei, pensando, às vezes, que poderia ter evitado, mas agora já é tarde, né? [risos]. (Humberto, entrevista, junho 2019)

Ele narrou o quanto ficou 'triste' após saber do diagnóstico, além de se sentir culpado pela maneira 'inconsequente' como construiu suas experimentações afetivas e sexuais como gay. A tristeza, entretanto, era-lhe uma velha conhecida. Com voz vacilante, contou sobre sua infância e todos os problemas que vivenciou desde então, passando pela experiência de abandono parental, viver em orfanatos até ser adotado, com 10 anos de idade, pela sua atual família, e ter sido diagnosticado com um tipo de câncer neurológico, há mais ou menos nove anos, identificado após sucessivas crises convulsivas. Tudo isso, 'inclusive o HIV', confluiu para um diagnóstico recente de transtorno do estresse pós-traumático que é, segundo seu psiquiatra, 'devido também à minha infância, a todos os problemas que eu tive. Inclusive, talvez, o HIV.

Antes desta 'treta', em março de 2019, eu havia entrevistado Júlia, uma mulher branca, heterossexual, com 46 anos de idade, com dois cursos superior e pós-graduação latu sensu, classe média, noiva e mora com sua filha em Maceió. $\mathrm{Na}$ 'treta', ela pareceu não ter percebido o sofrimento dele, tão centrada que estava na exposição de seus argumentos e pelo próprio fato de não se conhecerem (ele era novo no grupo). Júlia era uma das pessoas que participava ativa e assiduamente nos debates sobre 'política', talvez a mais convicta da necessidade de defender os direitos das pessoas que vivem com HIV/aids, mesmo estando 'calmíssima', pois detinha, segundo ela, não só a condição biológica - não ter aids e estar indetectável - mas também os meios materiais necessários para 'sair do país' caso seja necessário.

Ao dialogar com Humberto, mas também com outras pessoas que entrevistei, percebi que os posicionamentos de alguns deles nas 'tretas' sobre 'politica' nem sempre tinham a ver com ser ou não bolsonarista. No caso dele, tratava-se mais da evitação de 'pensamentos e noticias' que poderiam intensificar seus problemas de saúde, especialmente aqueles de ordem emocional. Ao longo de sua entrevista, Humberto narrou o quanto tentava 'tocar a vida', num movimento de fazer o mundo possível de ser habitado novamente, dadas as violências sucessivas e as condições de vulnerabilidade que marcaram sua vida. Ele fazia isso 
ao construir ativamente estratégias para enfrentar ou superar os sofrimentos decorrentes desses processos. Assim, a confiança na ação biológica dos medicamentos, e, especialmente, na garantia do acesso ao tratamento por meio de legislações era fundamental para seguir com a 'possibilidade de continuar vivendo igual a qualquer outra pessoa'. Ou seja, o acesso ao tratamento gratuito no SUS e a consequente cronificação da infecção pelo HIV lhe ajudava a amenizar as dores e as moralidades da aids, de maneira que as postagens sobre 'politica' se colocavam como assustadoras e ameaçadoras da confiança depositada no tratamento símbolo da política de aids biomedicalizada (SEFFNER; PARKER 2016), o que lhe produzia mais sofrimentos.

Outrossim, nas 'tretas' relacionadas à 'politica' que acompanhei foi possível evidenciar a maneira como se estabeleciam processos de diferenciação entre as pessoas que demonstravam conhecer o idioma político-institucional do Estado e suas gramáticas, o que implicava não só entender sobre 'política' e legislação, mas, nomeadamente, saber articular na escrita ${ }^{6}$ seus argumentos, assinalando, portanto, os diferentes pertencimentos sociais dos interlocutores, especialmente em termos de classe social, bem como os privilégios decorrentes deles. Em certa altura da 'treta' entre Júlia e Humberto, ficou evidente não só a maneira como esses eixos de diferenciação operavam, mas também como eles se relacionavam com certa disposição emocional que lhes permitiam continuar ou sair do debate.

[resposta ao comentário] Humberto, assunto encerrado pra você. E eu respeito o que você queira acreditar. Mas eu conheço BEM esse mundo político e as facetas dxs políticxs (já fui militante/ativista, já fui candidata): se deixarmos à deriva só nos confiando em Leis, na CFB [Constituição Federal Brasileira] estaremos deixando as coisas irem pro brejo. (Júlia)

[resposta ao comentário] Júlia, eu também conheço! Isso de tirar remédios do soropositivo não existe, cara! Se conforma! Pelo amor de Deus! (Humberto)

[resposta ao comentário] kkkkkkkkkkkkkkkkk... Como assim "se conforma"?! Bicho, por acaso, tu achas que eu curto que isso venha a acontecer?! Porque é o contrário! Agora, só não me peça pra viver no "Mundo de Alice" porque não tem nada a ver com minha personalidade. E quanto a você: meu, para de interagir se te faz mal! Você fica aí, todo nervoso, escolhe acreditar numa realidade diferente - que é um direito

\footnotetext{
${ }^{6}$ A linguagem escrita e seus códigos ocupava um lugar importante nas interações entre os interlocutores. A qualidade gramatical, o vocabulário, a ortografia e outros elementos textuais, por vezes, dava a conhecer as capacidades cognitivas e o capital cultural das pessoas. Assim, a linguagem escrita operava como elemento na produção de relações entre contextos online e off-line, especialmente por sugerir indícios dos pertencimentos sociais das pessoas, classificando-as e hierarquizando-as.
} 
seu, e quer impor que eu vá na sua?! Não. Quem tem que passar reto do que eu argumento é você. (Júlia)

[resposta ao comentário] Não querida. Eu acho que vc tá ficando muito obsessionada com essas coisas que não existen! Eu vivo nesse mundo real, aonde jamais vai acontecer uma coisa dessa que vc tá falando! Claro que eu vou interagir! Não é porquê eu tenho idéias diferentes das suas que não vou interagir! Eu em! Mas também não vou ficar 24 horas aqui batendo papo com vc! Vc disse a sua opinião, eu disse a minha, então chega ué! (Humberto)

[resposta ao comentário] "obsessionada" อิê O que vem a ser isso? Curiosa! Como eu falei Humberto, cada um ESCOLHE acreditar no que quiser e, como eu não posso lhe forçar a acreditar no que afirmo como realidade, mesmo embasando meus argumentos em fatos reais, leis, conjunturas políticas que envolvem Decretos assinados pelo atual Presidente, suas declarações a respeito de quem é soropositivo no passado que ele não retificou (corrigiu, mudou publicamente/oficialmente), relatos de PESSOAS que moram em Salvador, no interior da Paraíba e de Pernambuco do aviso que alguns arvs [antirretrovirais] serão racionados e sem previsão de voltar ao normal (não querem se expor, mas já dei contato de algumas pessoas daqui ativistas e bem realistas para as orientarem melhor)... Mesmo eu usando de todos esses argumentos bem pautados, você discorda do que afirmo. Não tenho o que fazer! Você rebate com argumentos SEM EMBASAMENTO SEGURO: NÃO TEM GARANTIA CONSTITUCIONAL, NÃO TEM EMENDA LÁ! HÁ UMA LEI COMPLEMENTAR E, SENDO LEI COMPLEMENTAR PODE SER DERRUBADA! Então, você usa um argumento falacioso, ao qual não posso me debruçar e aceitar. Cabe mesmo a você lidar com isso, respeitando também. Mas a questão é que você CONDICIONA a interação comigo aqui a eu concordar com você! Oi?! 9 Q Sem chances! E outras: ainda insinua supostos aspectos sobre mim (que eu nem entendi) em relação o que, PRA VOCÊ, são "coisas que não existem"! Cara, quem para por aqui de interagir com você sou eu, até pelo seu bem emocional. Agora... NÃO QUEIRA QUE EU VOLTE AQUI, VEJA VOCÊ NO DESESPERO E DIGA: "Humberto, EU CANTEI ESSA BOLA AQUI! EU A.V.I.S.E.I.!" Porque lugar de lutar por direitos É NAS RUAS! Aqui, a gente troca ideia e se articula. Só. Inté. Pax. (Júlia) 
[resposta ao comentário] Júlia, querida, ninguém tá te obrigando a concordar comigo pelo amor de Deus! Na minha opinião nada vai ser derrubado! Em lugar nenhum pode acontecer isso! Falacioso? Oi? Não mesmo! Pra concluir, temos opiniões diferentes! Boa tarde! E outra, eu fiz meu comentário nessa postagem, não pedi pra vc interagir comigo sobre o que eu escrevi! Então vc também não precisa ficar interagindo com tudo que eu opino aqui porque nunca teremos os mesmos pensamentos e opiniões! Obsessionada é OBCECADA! Meu teclado errou aqui, porque eu falo italiano também, mas no italiano é OSSESSIONATA! Você antes falou de interagir, eu também repito pra vc a mesma coisa, você não é obrigada a ficar interagindo comigo! (Humberto)

A 'treta' entre Júlia e Humberto sublinhou a maneira como, no grupo, as postagens sobre 'política' apontavam à insustentabilidade da "aids de agora" e o processo de construção do "(soro)positivo feliz" por meio da positivação destes sujeitos (CUNHA 2012: p.73), uma vez que recolocavam nos cotidianos dos interlocutores os riscos do retorno da "aids de antes". Destaca-se, assim, as interrelações entre emoções e confiança em sistemas peritos na produção da pessoa soropositiva. Em diálogo com Sangaramoorthy (2018), é possível afirmar que um aspecto fundamental na distinção entre a "aids de antes" e a "aids de agora" é a perspectiva biomédica de que a primeira era uma doença aguda e letal, enquanto que a segunda é uma condição crônica, com a qual é possível viver. Biomedicamente, a cronicidade da infecção pelo HIV é construída como uma evolução natural e como uma realidade médica inevitável. Para a autora, entretanto, esta perspectiva "obscurece a cronicidade do HIV como induzida pelos avanços biotecnológicos [ou seja, a natureza do vírus continua letal] e como uma crise em curso em comunidades particulares" (SANGARAMOORTHY 2018: p.3).

Portanto, as postagens sobre 'politica' e as 'tretas' se colocavam nas interações entre os interlocutores como capazes de abrir frestas na linearidade dos discursos biomédico e oficial. Fizeram isso na medida em que evidenciavam a precariedade da construção da "aids de antes" como uma crise do passado, uma vez que sucumbiu diante dos avanços biotecnológicos, em primeira mão, e das políticas públicas que tais avanços ajudaram a formular, em segunda. As sensações de pânico, terror, incerteza e medo narradas pelos interlocutores, bem como as gramáticas política e emocional das 'tretas' coexistiam com a confiança, o otimismo, a harmonia e as possibilidades de ajuda mútua vivenciadas no grupo - uma vez que a socialidade ali não assumiu um caráter monotemático.

\section{Renitências}

Os achados etnográficos analisados neste artigo deixaram em relevo as renitências de uma aids e suas temporalidades em se dobrar ao tempo disponibilizado pela biomedicina. A "aids de agora", crônica, se erigiu em torno da concepção e da confiança na finitude das 
temporalidades da "aids de antes" que foram, na visão de Sangaramoorthy (2018), "adiadas, e não eliminadas" como apostou a medicina. Para a autora,

Tais narrativas destacam o HIV como uma crise do passado e uma condição crônica no presente, induzida por avanços biotecnológicos e investimentos políticos e econômicos. Elas também sinalizam finais futuros, que são imaginados em relação à uma ruptura com o passado e à criação de novas economias morais onde o estigma em relação aos sofredores é reduzido e o acesso ao tratamento que salva vidas é padrão (SANGARAMOORTHY, 2018, p. 11).

Neste sentido, as postagens sobre 'política' e as 'tretas' nos ajudam a pensar sobre estas temporalidades e o quanto passado, presente e futuro são precários, especialmente quando se trata de uma epidemia cuja história tem evidenciado as disputas de significação (TREICHLER 1987) que lhe constituíram e permanecem operantes. Nesse sentido, a construção da "aids de agora" como apartada, no tempo, da "aids de antes" mostrou-se, no contexto desta investigação, menos como uma ruptura e mais como continuidade.

Tais achados se coadunam aos de Biehl $(2007 ; 2011)$, uma vez que o autor enfatiza o quanto a narrativa que construiu a resposta brasileira à epidemia de aids como bem sucedida deixou à deriva um conjunto de pessoas cujas experiências com o HIV/aids foram modeladas por seus pertencimentos sociais em termos de classe, gênero, raça e lugar, e, nomeadamente, por suas trajetórias de abjeção e marginalização. Ou seja, a "aids de antes”, no Brasil, nunca deixou de existir, como em outros lugares, a exemplo de Uganda. McGrath et al. (2014) evidenciaram que neste país o tratamento antirretroviral está disponível desde os anos 1990, podendo ser comprado ou adquirido ao participar de pesquisas científicas. Os autores destacam que atualmente há antirretrovirais baratos e gratuitos, mas a procura excede a disponibilidade. Em 2012, apenas 23\% das crianças, $42 \%$ dos homens e $55 \%$ das mulheres recebiam gratuitamente os medicamentos - o que chama a atenção para as geopolíticas da aids. De acordo com Biehl (2011), a política brasileira de aids se implementou por meio da constituição de "ilhas de assistência médica" (p. 279) e, fora delas, manteve em curso a morte social de grupos marginalizados afetados pela aids. Exemplo disso era a maneira como alguns casos de óbito por aids em Salvador-BA se tornavam oficialmente visíveis ao Estado (por meio de notificações e outras formas de registro oficial) e outros não.

À revelia desse cenário, a socialidade no grupo, como já assinalado, avivava a crença nessa "aids de agora". Nesse contexto, as gramáticas política e emocional que davam formas e sentidos às 'tretas' engendradas nos debates sobre a conjuntura política nacional e seus rebatimentos nas ações estatais relacionadas à aids deixaram em relevo o quão frágil eram os fios com que se teciam o clima otimista e harmonioso que caracterizava a socialidade no grupo. Ao mesmo tempo, permitiu aprofundar a dimensão seletiva do acolhimento produzido entre os membros do grupo, conforme discutimos em Damasceno et al. (2019), 
demonstrando o quanto as interações produzidas em ambientes online não constituem uma realidade alheia ao mundo off-line; pelo contrário, nesses espaços podem se intensificar experiências de diferenciação e hierarquização sociais.

Ademais, as 'tretas' colaboraram para a interpretação dos significados atribuídos pelos interlocutores às políticas públicas de saúde, o que possibilitou analisar o lugar do Estado nessas políticas, como também na produção e reprodução de situações sociais que se localizam na sociogênese ou na intensificação de experiências de sofrimento social. Cumpre destacar a forma como as políticas públicas podem atuar como tecnologias políticas que participam de processos de subjetivação e de governamentalidade, na medida em que são construídas e representadas sob o "manto da neutralidade" da linguagem cientítica e racional-legal que retira sua natureza propriamente política e o Estado como um agente central (SHORE; WRIGHT 1997). No caso examinado, o apagamento da ação estatal permitia a confiança no acesso ao tratamento como "balas mágicas" (BIEHL 2011: p.273), uma vez que se tratava de "um estado que está farmaceuticamente presente (através do mercado), mas em geral institucionalmente ausente". Este modo de configuração das políticas públicas colaborou para um desconhecimento, por parte dos interlocutores, da história da epidemia no país e, consequentemente, das suas íntimas relações com o movimento social de aids.

Ao fazer isso, o Estado brasileiro e agências internacionais permitiram uma fantasiosa "reinvenção do tempo" quando sinalizavam a um futuro livre da aids, como assinalado por Sangaramoorthy (2018: p.11), e deixou de fora dos seus discursos e práticas os efeitos do "envelhecimento, a toxicidade dos antirretrovirais de longo prazo, os sistemas de saúde inexistentes ou em desmonte e o aumento das iniquidades sociais, econômicas e políticas [que] dão lugar a um senso persuasivo de incerteza que torna o HIV menos uma 'ruptura' com vidas temporalmente 'normais' do que uma experiência nada excepcional e comum em muitos contextos". Em nossa análise, as postagens sobre 'politica' e as 'tretas' assinalavam tais processos e desenhavam cenários distópicos que se distinguiam desse futuro imaginado, uma vez que traziam para perto a crise do passado e afetavam os arranjos emocionais elaborados para viver com HIV/aids, como bem colocou Humberto.

Há que se destacar o quanto as relações entre emoções e políticas se imbricam na produção de sofrimento social. Embora a relação entre HIV/aids e sofrimento social já esteja bem relatada na literatura socioantropológica (FARMER 1997; 2003), o aspecto mais relevante dos resultados deste estudo diz respeito ao modo como o Estado exerce seu poder por meio da produção de saberes, discursos, práticas, políticas públicas e tecnologias que visam a amenizar experiências de sofrimento, a prolongar a vida, a prevenir doenças e mortes, sem, contudo, destacar a própria dependência de suas ações para que isso se efetive e se mantenha. Se, por um lado, ao fazer isso, construiu uma "aids de agora" capaz de atar a "aids de antes" no passado e aliviar a dor de saber-se vivendo com uma condição impregnada de estigmas, por outro, invisibilizou a cronicidade da infecção como uma crise constante (SANGARAMOORTHY 2018) por meio da cortina de fumaça que o próprio Estado ergueu. 
Para alguns interlocutores, tal invisibilização se colocou como capaz de intensificar experiências de sofrimento social nos momentos em que a fumaça parecia se dissipar na esteira de debates no grupo. Como sustentado por Sangaramoorthy (2018: p.11), "a cronicidade do HIV como crise sinaliza não um fim, mas o contínuo desdobramento e reconfiguração de vidas sociais e biológicas em meio a riscos, precariedade e fragmentação". Ou seja, estamos diante de um problema cujo enfrentamente se produz e se mantém não pela linearidade progressiva dos discursos hegemônicos (científico, político, econômico, etc.), mas pela sua permanência, pelo seu espiralamento, pela sua renitência.

Aspecto igualmente relevante e que assinalo como questão para investigações futuras é o fato de que a 'treta' entre Júlia e Humberto, por exemplo, nos oferece elementos para indagar as inflexões da conformação da política brasileira de aids na produção da pessoa soropositiva. Ambos interlocutores foram diagnosticados com HIV/aids nos anos 2010, num momento de hegemonia dos processos de biomedicalização da resposta brasileira à epidemia e da consolidação de uma "ontologia individual liberal" (SEFFNER; PARKER 2016), cujos focos são as metas biomédicas estabelecidas globalmente e os processos de individualização e de responsabilização pelo próprio cuidado. Como apontam Seffner e Parker (2016), esta "ontologia individual liberal" recolocou o problema da aids não como uma questão política, mas como individual, de maneira que colaborou para o esvaziamento (não sem resistências) dos espaços de mobilização e de diálogos com sujeitos coletivos e movimentos sociais, ao que acrescento o fato de ter secundarizado (ou quiçá nublado) o papel do Estado.

Ao passo que as políticas públicas e as narrativas do "fim da aids" buscam mitigar o sofrimento humano que a epidemia suscita, a 'treta' em questão nos indica a forma como podem intensificá-lo. Tais políticas e narrativas fazem isso ao engendrar processos de subjetivação de pessoas soropositivas que envolvem, em algum grau, uma virada subjetiva, via tecnologias do self (autocuidado, automonitoramento, autodisciplinamento, etc.) - estas velhas conhecidas da biomedicina no manejo do cuidado de pessoas com adoecimentos de longa duração -, a responsabilização dos indivíduos e o alheamento destes da complexidade histórica, social e política da epidemia, na medida em que estimulam a confiança na biomedicina e em legislações específicas. Esse processo, pelo que foi possível observar nesta pesquisa, é simultaneamente produtor e produto dessa "ontologia individual liberal", de maneira que intensifica a individualização e o delineamento do viver com o HIV/aids como um segredo, um problema pessoal recortado das teias históricas, sociais e políticas. A socialidade no grupo, nesse contexto, além de ter como vigas esses elementos, parecia compor um espaço interacional também simultaneamente produto e produtor desse cenário político mais amplo. A despeito da importância do grupo investigado ser um espaço para acolhimento e ajuda mútua, é mister assinalar o papel fundamental que a reunião dessas pessoas e a socialidade que produziam, bem como os conteúdos que engendravam via compartilhamentos de saberes e de experiências, desempenhava na reprodução e manutenção social do fenômeno em tela. Com isso, não quero afirmar que as pessoas 
membras do grupo se colocavam acrítica e passivamente à mercê dessas operações macroestruturais, visto que a própria existência das 'tretas' sinalizavam o contrário: havia uma reflexão, uma crítica e um conhecimento daquilo que se passava.

Os resultados apresentados neste texto lançam luz à maneira como essa "ontologia individual liberal" participava da produção de subjetividades fortemente assentadas numa lógica individualizante e da construção de uma socialidade alinhada ao "cada um por si". No entanto, mesmo que esses "sis" se reunissem e compartilhassem aspectos de suas experiências comezinhas com o vírus, pareciam não ter sido capazes de acolher um debate político sobre a própria condição de viver com HIV/aids, alargando o próprio sentido de 'politica'. É nesse contexto que as postagens sobre 'política' se mostraram como capazes de desestabilizar, ainda que superficialmente, os alicerces desse empreedimento biomédico e liberal. Fez isso na medida em que deixou nuas as estratégias de governo da vida de pessoas que vivem com HIV/aids, o perigo do discurso da cronicidade da infecção pelo HIV e do otimismo que ele anima. O cenário de desmonte da política de aids, associado aos demais problemas sociais vinculados à epidemia, abalou o pilar fundacional (tratamento-tempo-normalidade) que a política de saúde construiu e que a socialidade no grupo reproduzia, o que intensificou para alguns interlocutores experiências de dor e sofrimento, na medida em que evidenciou o quanto a confiança no discurso da cronicidade pode propiciar condições para violação de direitos das pessoas que vivem com HIV/aids, para a invisibilidade social e, consequentemente, reforçar o próprio desmonte da política como um espiral de violências políticas.

Portanto, pensar as temporalidades da aids não como lineares e sucessivas, mas, sim, como renitentes nos possibilita por em análise os próprios movimentos capitaneados pelas relações entre Estado, biotecnologia e mercado cujo intuito é fazer esmaecer não apenas estas relações, como as próprias permanências, continuidades, disputas, tensões e precariedades que compõem as respostas políticas à epidemia. Outrossim, alçar a categoria tempo para o centro da análise permitiu lidar com ela como um catalizador das profundas relações entre políticas, emoções e socialidades, uma vez que ofereceu um ponto de vista rentável para o estudo das narrativas de adoecimento psíquico relatadas por pessoas membras do grupo não como uma doença a priori, mas como um idioma capaz de expressar sofrimento social. Interpretar tais experiências de mal-estar sob esta ótica se mostrou analiticamente produtivo, nomeadamente por inserir a discussão não na dimensão intrapsíquica de cada pessoa, mas no caldo relacional entre indivíduo e sociedade que produz esta própria psiquê.

\section{Referências Bibliográficas}

AGOSTINI, Rafael; ROCHA, Fátima; MELO, Eduardo; MAKSUD, Ivia. (2019). A resposta brasileira à epidemia de HIV/AIDS em tempos de crise. Ciência \& Saúde Coletiva, v. 24, n. 12, pp. 4599-604, 2019. 
BASTOS, Cristiana. (2002). Ciência, poder, acção: as respostas à Sida. Lisboa: Imprensa de Ciências Sociais.

BIEHL, João. (2007). Will to live: AIDS therapies and the politics of survival. Princeton: Princeton University Press.

BIEHL, João. (2011). Antropologia no campo da saúde global. Horizontes Antropológicos, Porto Alegre, v. 17, n. 35, pp. 257-96.

CUNHA, Claudia Carneiro da. (2012).Os muitos estudos de uma "sexualidade soropositiva": o caso dos jovens vivendo com HIV/AIDS. Sexualidad, Salud y Sociedad - Revista Latinoamericana, Rio de Janeiro, v.10, pp. 70-99.

DAMASCENO, Éverson de Brito; CORTEZ, Lumena Cristina de Assunção; FERREIRA, Fábbio de Souza; SILVA, Mercês de Fátima dos Santos; MELO, Lucas Pereira de. (2019). "Algo tão simples de viver e controlar, mas difícil de compartilhar e defender": HIV/Aids, segredos e socialidades em uma rede social on-line. Interface - Comunicação, Saúde, Educação, Botucatu, v. 23, p. e180506.

FARMER, Paul. (1997). On suffering and structural violence: a view from below. In: KLEINMAN, Arthur; DAS, Veena; LOCK, Margareth (ed.). Social suffering. Berkeley: University of California Press. pp. 261-83.

FARMER, Paul. (2003). Pathologies of power: health, human rights, and the new war on the poor. Berkeley: University of California Press.

GIDDENS, Anthony. (1991). As consequências da modernidade. São Paulo: Editora Unesp.

HARAWAY, Donna. (1995). "Saberes localizados: a questão da ciência para o feminismo e o privilégio da perspectiva parcial". Cadernos Pagu, Campinas, v.5, pp. 7-41.

KLEINMAN, Arthur; DAS, Veena; LOCK, Margareth. (1997). Introduction. In: KLEINMAN, Arthur; DAS, Veena; LOCK, Margareth. (Eds). Social suffering. Berkeley: University of California Press. pp. ix-xxvii.

MARX, Karl; ENGELS, Friedrich. (2005). Manifesto comunista. $4^{\circ}$ reimp. São Paulo: Boitempo.

McGRATH, Janet W; WINCHESTER, Margaret S.; KAWA-MAFIFIGI, David; WALAKIRA, Eddy; NAMUTIIBWA, Florence; BIRUNGI, Judith; SSENDERGYE, George; NALWOGA, Amina; KYARIKUNDA, Emily; KISAKYE, Sheila; AYEBAZIBWE, Nicolas; RWABUKALI, Charles B. (2014). "Challenging the paradigm: anthropological perspectives on HIV as a chronic disease". Medical Anthropology, Philadelphia, v. 33, n. 4, pp. 303-17

RABINOW, Paul. (1996). Essays on the anthropology of reason. Princeton: Princeton University Press.

SANGARAMOORTHY, Thurka. (2018). Chronicity, crisis, and the "end of AIDS". Global Public Health. London, v. 13, n. 8, pp. 982-96.

SEFFNER, Fernando; PARKER, Richard. (2016). Desperdício da experiência e precarização da vida: momento político contemporâneo da resposta brasileira à aids. Interface Comunicação, Saúde, Educação, Botucatu, v. 20, n. 57, pp. 293-304. 
SHORE, Cris; WRIGHT, Susan (ed.). (1997). Anthropology of policy: critical perspectives on governance and power. London: Routledge.

TREICHLER, Paula. (1987). "AIDS, homophobia and biomedical discourses: an epidemic of signification". October, Cambridge, v. 43, p. 31-70.

VITORINO, Maíra Moraes; RENAULT, David. (2020). A irrupção da fake news no Brasil: uma cartografia da expressão. Comunicação \& Sociedade, São Bernardo do Campo, v. 42, n. 1, pp. 229-59.

\section{Lucas Pereira de Melo}

Doutor em Enfermagem pela Escola de Enfermagem da USP. Professor da Universidade de São Paulo, campus Ribeirão Preto.

Recebido em: 18/09/2020

Aceito para publicação em: 18/12/2020 